\title{
The Effect of Employee Competence on Increasing Employee Motivation in Sumut Bank of Sharia Unit, North Sumatera
}

\author{
Nur M Ridha Tarigan', Heru Setiawan² \\ ${ }^{1}$ Universitas Islam Sumatera Utara Medan, Indonesia \\ ${ }^{2}$ Universitas Pasundan, Bandung, Indonesia \\ nur.mridha@fe.uisu.ac.id
}

\section{Abstract}

This study aims to analyze the effect of employee competence on increasing employee motivation in Sumut Bank of Sharia Unit, North Sumatera. This research uses descriptive and verification methods. The place of research was conducted at Sumut Bank of Sharia Unit, North Sumatera. Considering the nature of this research is descriptive and verification, the research method used is descriptive survey and explanatory survey method. The type of investigation in this research is causality, which is testing the causal relationship between independent variables, intervening variables, moderating variables and dependent variables. The unit of analysis in this study is the employees at Sumut Bank of Sharia Unit, North Sumatera. The result shows that Competence in Sumut Bank of Sharia Unit, North Sumatera is perceived as poor to good. The highest average value is an indicator of the ability of employees to express narratives, meaning that employees actually have the ability to carry out their duties but are still not optimal. Nevertheless there are still some weaknesses in the indicator of the ability of employees to holistically look at problems in their lives. The experts also agree with the findings of researchers, and said competence still dominates important factors in the banking business, even sharia bank employees need to have special competencies.
Keywords

Employee competence; motivation; Sumut Bank; sharia unit

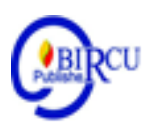

The banking world is inseparable from human life, because all human activities involve finance and require banking facilities. In the banking world, institutions that play an important role are banks, the main function of banks is collecting funds from the public and channeling them back in various forms of investment that can generate profits. Therefore, the bank is a business segment whose activities are largely regulated by the government (Siamat, 2005: 275). The development of bank institutions runs dynamically and has very rapid progress, especially Islamic banking. Islamic banks are increasingly in demand by the public, especially those who are Muslim because of the tendency of Islamic banks to maintain good financial cycles even in times of economic crisis in Indonesia, and Islamic banks provide financial transaction services that are carried out according to moral values and sharia principles. in Islam. In the process of Islamic Banks are required to conduct activities that avoid usury, this is a challenge for Islamic Banks.

Islamic banking is a bank institution that is managed with Islamic principles. The presence or establishment of Islamic banking, should depart from objective conditions with the existence of the people's decision or economic demands. Then, for an Islamic bank to survive and develop, its institutional management must be credible and the implementation of its business activities must be professional. The development of Islamic banks in Indonesia, 
of course, there must be support from quality human resource management. Because, it is not possible for a sharia bank to achieve success without qualified HR management.

One problem that is no less complex is faced by Islamic banks, namely: First, the problem of human resources. In this case the rise of Islamic banking in Indonesia is not matched by adequate human resources. Especially HR who has background knowledge in the field of Islamic banking. Secondly, the lack of Islamic banking academics, where much education is more oriented to the introduction of conventional economics than Islamic economics, which in turn is concerned with Islamic economics especially Islamic banking is ignored and lacking attention.

One factor that determines improving the performance of bank institutions is the availability of qualified human resources and supporting infrastructure. Qualified human resources needed by Islamic banks are human resources who scientifically understand the concept of Islamic banks and Islamic economics, and psychologically they have a high Islamic spirit. HR who only understand the knowledge of Islamic banks and Islamic economics, but do not have a high Islamic spirit, then the knowledge is like there is no spirit. So that in his daily activities he has no sense of belonging and a sense of responsibility towards the progress of Islamic banks.

One other factor that influences employee motivation is competency, according to Sedarmayanti (2009: 127), "Competence is a key determining factor for someone in producing excellent performance. In a collective situation, competence is a key determining factor in shaping a good organizational culture ", so competency for employees is very important.

Based on the results of the pre-survey conducted by researchers by distributing questionnaires to 20 employees. The pre-survey results related to competencies are shown in Table 1.

Table 1. Competencies of Bank Syariah Employees in North Sumatera Unit

\begin{tabular}{|c|c|c|c|c|c|c|}
\hline Statement & Excellent & Good & Poor & Bad & Worst & Total \\
\hline $\begin{array}{c}\text { Intellectual } \\
\text { competence }\end{array}$ & 2 & 5 & 10 & 2 & 1 & 20 \\
\hline $\begin{array}{c}\text { Emotional } \\
\text { competence }\end{array}$ & 2 & 7 & 8 & 3 & 0 & 20 \\
\hline Social competence & 3 & 6 & 8 & 2 & 1 & 20 \\
\hline Spiritual competence & 2 & 4 & 10 & 2 & 2 & 20 \\
\hline Frequency & 9 & 22 & 36 & 9 & 4 & 80 \\
\hline Score & 45 & 88 & 108 & 18 & 8 & 267 \\
\hline Precentage & $16,85 \%$ & $32,96 \%$ & $40,45 \%$ & $6,74 \%$ & $2,99 \%$ & $100,00 \%$ \\
\hline Average & & & & & & 3,33 \\
\hline
\end{tabular}

Source: Data processed from the questionnaire (2017)

From the data in Table 1. It shows that the average results of the questionnaire were 3.33 , if referring to the interpretation of the assessment criteria regarding employee competence at the North Sumatra Sharia Unit of North Sumatra Province included in the 
category of "quite good". So the conclusions from the results of the pre-survey as shown in Table 1.5 shows that employee competency is not optimal.

Based on the description above, the authors are interested in conducting more in-depth research on the problem with the research title "The Effect of Employee Competence on Increasing Employee Motivation in the North Sumatra Bank of Sharia Unit, North Sumatra"

\subsection{Competence}

\section{Review Literature}

Michael Armstrong in Sudarmanto (2009: 46), Competence is what people bring to a job in the form of different types and levels of behavior. Competence determines aspects of the company's performance process. According to Noe (2002: 94), Competence is the ability of individuals to carry out the tasks of their profession which is a combination of knowledge, skills and attitudes.

\section{a. Competency Characteristics}

According to Spencer and Spencer in Rivai (2009: 306), states that there are 5 (five) competency characteristics, which are as follows:

- Motives (Motives), which is something that is consistently thought or desired by someone who causes action. Motives encourage, direct and choose behavior towards certain actions or goals.

- Traits, namely physical characteristics and consistent responses to situations or information. Reaction speed and eye sharpness are physical characteristics of a combat pilot's competence.

- Self Concept (Self Concept), which is the attitude, value or self image or image of someone's dori. Examples of confidence are beliefs that they can be effective in a variety of situations, are part of his concept.

- Knowledge (knowledge), which is information that is owned by someone, especially in a specific field. Knowledge is a complex competency. Normally knowledge tests measure the ability to choose the most correct answer, but cannot see whether a person can do work based on the knowledge he has.

- Skills (Skills) ", namely the ability to carry out certain physical and mental tasks. Mental competence or cognitive skills include analytical and conceptual thinking.

\section{b. Competency Function}

Ruky (2003), argues the concept of competence is becoming increasingly popular and has been widely used by work units, especially large companies for various reasons, namely:

- Clarify work standards and expectations to be achieved.

- Employee selection tool.

- Maximizing productivity.

- The basis for developing a remuneration system.

- Facilitate adaptation to change.

- Align work behavior with organizational values.

c. Competency Category

As according to Sybll K. Romley (2008) related to competence said:

"Most authorities recognize that competencies generally fall into two categories hard measures and soft measures. Hard measures are more clearly definable and straight-forward-they are the make-or-break requirements for being able to do a job. They are usually listed in job descriptions as requirements or desired qualificationsacademic achievement, professional certifications and licenses, years of experience, technical knowledge, et cetera. Speaking a language, typing 50 words per minute and 
holding a master's degree are examples. Soft measures are the more subtle behaviors revealed in certain circumstances that often make the difference between success and failure-attitude, leadership, communication, cultural fit, interpersonal effectiveness, et cetera. They are the reason why someone with the right academic qualifications might not succeed in a position. They are often deeply embedded in a company's culture and provide a way of measuring what happens when individuals operate in the real world, where "the rubber meets the road " Properly established soft measures provide the foundation for a company's performance management program."

Based on this opinion can be interpreted as follows: Most authors acknowledge that competencies are generally divided into two categories, namely competencies in the hard category and the soft category. The crackdown is more clearly defined and straight forward, they are making or violating the requirements to be able to do the work. They are usually listed in the job description as requirements or qualifications desired for academic achievement, professional certification and licensing, years of experience, technical knowledge, and so on.

Subtle actions, more subtle behavioral steps are expressed in certain circumstances which often make the difference between success and failure of attitude, leadership, communication, compatibility / habits with work, effectiveness of employee relations etc. They reasoned why someone with the right academic qualifications might not succeed in the best position.

\subsection{Work Motivation}

According to Robbins (2010: 109) motivation refers to the process by which a person's efforts are energized, directed, and sustained towards achieving a goal. " This definition has 3 (three) key elements: energy, direction and perseverance.

According to Siagian (2002: 102) motivation is a driving force for someone to make the largest possible contribution for the success of an organization to achieve its goals. With the understanding that the achievement of organizational goals means also the personal goals of the members of the organization concerned are also met.

Workers do work expecting compensation to meet their personal needs and goals to realize their work performance. If someone has the motivation to achieve their personal goals, then they must improve performance. Increasing one's performance will improve organizational performance. Thus, increasing one's motivation, will improve the performance of individuals, groups, and organizations.

Motivation (motivation) in management is only intended for human resources in general and in particular subordinates. Motivation questions how to direct the power and potential of subordinates to be willing to work together productively to achieve and realize the specified goals. One of the important things that must be done by a leader is to provide motivation or encouragement to improve employee performance.

Chung \& Megginson in Faustino Cardoso (2003: 177) states that "motivation is defined as goal directed behavior, it concerns the level of effort one exerts in pursuing a goal, it is closely rolated to employee satisfaction and job performance". (Motivation is formulated as a behavior aimed at the target, motivation is related to the level of effort done by someone in pursuing a goal, motivation is closely related to employee satisfaction and job performance). Motivation according to Greenberg and Baron (2003: 190) is a series of processes that arouse (direct), direct (direct), and maintain (maintain) human behavior toward achieving goals. Generating relates to the impetus behind the action, while maintaining or maintaining behavior relates to how long a person will continue to strive to achieve the goal. 


\section{Research Method}

This research uses descriptive and verification methods. The place of research was conducted at Sumut Bank of Sharia Unit, North Sumatera. Considering the nature of this research is descriptive and verification, the research method used is descriptive survey and explanatory survey method. The type of investigation in this research is causality, which is testing the causal relationship between independent variables, intervening variables, moderating variables and dependent variables. The unit of analysis in this study is the employees at Sumut Bank of Sharia Unit, North Sumatera.

\section{Discussion}

\subsection{Test Results of the Validity of Competency Variable Instruments}

Testing the validity of the instrument used as 29 item statements distributed to 150 samples. The results of testing the validity of the instrument can be seen in Table 2 as follows:

Table 2. Test Results of the Validity of Competency Variable Instruments

\begin{tabular}{|c|c|c|c|c|}
\hline Variable & $\begin{array}{l}\text { Question } \\
\text { Number }\end{array}$ & r-critical & r-table & Information \\
\hline & 1 & 0.6974 & 0.300 & Valid \\
\hline & 2 & 0.6848 & 0.300 & Valid \\
\hline & 3 & 0.6797 & 0.300 & Valid \\
\hline & 4 & 0.7428 & 0.300 & Valid \\
\hline & 5 & 0.7685 & 0.300 & Valid \\
\hline & 6 & 0.7254 & 0.300 & Valid \\
\hline & 7 & 0.6465 & 0.300 & Valid \\
\hline & 8 & 0.7216 & 0.300 & Valid \\
\hline & 9 & 0.7067 & 0.300 & Valid \\
\hline & 10 & 0.7084 & 0.300 & Valid \\
\hline & 11 & 0.6716 & 0.300 & Valid \\
\hline & 12 & 0.7925 & 0.300 & Valid \\
\hline & 13 & 0.8016 & 0.300 & Valid \\
\hline & 14 & 0.7366 & 0.300 & Valid \\
\hline & 15 & 0.7430 & 0.300 & Valid \\
\hline & 16 & 0.7551 & 0.300 & Valid \\
\hline & 17 & 0.7148 & 0.300 & Valid \\
\hline & 18 & 0.7526 & 0.300 & Valid \\
\hline & 19 & 0.8115 & 0.300 & Valid \\
\hline & 20 & 0.7660 & 0.300 & Valid \\
\hline & 21 & 0.7113 & 0.300 & Valid \\
\hline & 22 & 0.7790 & 0.300 & Valid \\
\hline & 23 & 0.7037 & 0.300 & Valid \\
\hline & 24 & 0.6849 & 0.300 & Valid \\
\hline & 25 & 0.8316 & 0.300 & Valid \\
\hline
\end{tabular}




\begin{tabular}{|l|l|l|l|}
26 & 0.7699 & 0.300 & Valid \\
\hline 27 & 0.7670 & 0.300 & Valid \\
\hline 28 & 0.7511 & 0.300 & Valid \\
\hline 29 & 0.7507 & 0.300 & Valid \\
\hline
\end{tabular}

Based on Table 2 above, the questionnaire is to be known that all instruments on the competency variable have values greater than 0.300 . The conclusion is that all instruments on the variables are declared to be all valid, that is, they have good accuracy in measuring the variables.

\subsection{Employee Perception of Competence}

Competence is measured by 29 question items with 4 (four) dimensions, namely intellectual, emotional, social and spiritual. The following are the results of a study of 29 question items raised to measure the competency variable. Based on the results of data collection that refers to the questionnaire, scores obtained range of data values for the variables represented by 29 question items for 150 Employees.

Table 3. Respondents' Responses to Competency Variables

\begin{tabular}{|c|c|c|c|c|c|c|c|c|}
\hline \multirow{2}{*}{ No } & \multirow{2}{*}{ Statement } & \multicolumn{5}{|c|}{ Alternative Answers } & \multirow{2}{*}{ Average } & \multirow{2}{*}{$\begin{array}{l}\text { Standard } \\
\text { Deviation }\end{array}$} \\
\hline & & TD & D & $\mathbf{F}$ & $\mathbf{A}$ & SA & & \\
\hline 1 & $\begin{array}{l}\text { The willingness of } \\
\text { employees to increase } \\
\text { knowledge }\end{array}$ & 39 & 94 & 15 & 2 & 0 & 3,566 & 0,880 \\
\hline 2 & $\begin{array}{l}\text { The ability of employees } \\
\text { to increase job certainty }\end{array}$ & 40 & 92 & 17 & 1 & 0 & 3,800 & 0,883 \\
\hline 3 & $\begin{array}{l}\text { The ability of employees } \\
\text { to develop work initiatives }\end{array}$ & 41 & 93 & 15 & 1 & 0 & 3,800 & 0,878 \\
\hline 4 & $\begin{array}{l}\text { The ability of employees } \\
\text { in the mastery of } \\
\text { information }\end{array}$ & 36 & 99 & 14 & 1 & 0 & 3,800 & 0,867 \\
\hline 5 & $\begin{array}{l}\text { The ability of employees } \\
\text { to think analytically }\end{array}$ & 40 & 92 & 18 & 0 & 0 & 2,667 & 0,878 \\
\hline 6 & $\begin{array}{l}\text { The ability of employees } \\
\text { to think conceptually }\end{array}$ & 39 & 92 & 17 & 2 & 0 & 3,566 & 0,886 \\
\hline 7 & $\begin{array}{l}\text { The ability of employees } \\
\text { to think practically }\end{array}$ & 40 & 93 & 16 & 1 & 0 & 3,800 & 0,880 \\
\hline 8 & $\begin{array}{l}\text { The ability of employees } \\
\text { in language acquisition }\end{array}$ & 40 & 89 & 19 & 2 & 0 & 3,566 & 0,893 \\
\hline 9 & $\begin{array}{l}\text { The ability of employees } \\
\text { to express reasoning }\end{array}$ & 30 & $\begin{array}{c}10 \\
4\end{array}$ & 15 & 1 & 0 & 3,800 & 0,858 \\
\hline 10 & $\begin{array}{l}\text { Sensitivity and mutual } \\
\text { understanding between } \\
\text { employees }\end{array}$ & 51 & 79 & 19 & 1 & 0 & 3,800 & 0,895 \\
\hline 11 & $\begin{array}{l}\text { Employee concern for } \\
\text { customer satisfaction }\end{array}$ & 53 & 91 & 4 & 2 & 0 & 3,566 & 0,848 \\
\hline 12 & $\begin{array}{l}\text { The ability of employees } \\
\text { in self-control }\end{array}$ & 59 & 77 & 13 & 1 & 0 & 3,800 & 0,883 \\
\hline 13 & Confidence of employees & 58 & 79 & 13 & 0 & 0 & 2,822 & 0,876 \\
\hline
\end{tabular}




\begin{tabular}{|c|c|c|c|c|c|c|c|c|}
\hline & in completing work & & & & & & & \\
\hline 14 & $\begin{array}{l}\text { The ability of employees } \\
\text { to adapt to the work } \\
\text { environment }\end{array}$ & 52 & 89 & 9 & 0 & 0 & 2,985 & 0,860 \\
\hline 15 & $\begin{array}{l}\text { Employee commitment to } \\
\text { the organization }\end{array}$ & 49 & 91 & 9 & 0 & 0 & 2,963 & 0,889 \\
\hline 16 & $\begin{array}{l}\text { Employee influence on } \\
\text { social impact }\end{array}$ & 39 & 97 & 14 & 0 & 0 & 2,787 & 0,864 \\
\hline 17 & $\begin{array}{l}\text { Employee awareness in } \\
\text { organizing }\end{array}$ & 39 & 96 & 15 & 0 & 0 & 2,755 & 0,867 \\
\hline 18 & $\begin{array}{l}\text { The ability of employees } \\
\text { to build working } \\
\text { relationships }\end{array}$ & 47 & 91 & 12 & 0 & 0 & 2,858 & 0,867 \\
\hline 19 & $\begin{array}{l}\text { The ability of employees } \\
\text { to develop other people }\end{array}$ & 45 & 93 & 12 & 0 & 0 & 2,858 & 0,865 \\
\hline 20 & $\begin{array}{l}\text { The ability of employees } \\
\text { to direct subordinates or } \\
\text { coworkers }\end{array}$ & 54 & 78 & 18 & 0 & 0 & 2,667 & 0,886 \\
\hline 21 & $\begin{array}{l}\text { The ability of employees } \\
\text { to work in team work }\end{array}$ & 52 & 84 & 14 & 0 & 0 & 2,787 & 0,877 \\
\hline 22 & $\begin{array}{l}\text { The ability of employees } \\
\text { to build leadership in } \\
\text { groups }\end{array}$ & 41 & 94 & 15 & 0 & 0 & 2,755 & 0,870 \\
\hline 23 & $\begin{array}{l}\text { The ability of employees } \\
\text { to be flexible and adaptive } \\
\text { to the beliefs held }\end{array}$ & 42 & 93 & 15 & 0 & 0 & 2,755 & 0,872 \\
\hline 24 & $\begin{array}{l}\text { Employees have the } \\
\text { awareness to carry out } \\
\text { worship according to their } \\
\text { beliefs }\end{array}$ & 65 & 73 & 12 & 0 & 0 & 2,858 & 0,873 \\
\hline 25 & $\begin{array}{l}\text { The ability of employees } \\
\text { to overcome the problems } \\
\text { suffered }\end{array}$ & 49 & 87 & 14 & 0 & 0 & 2,787 & 0,875 \\
\hline 26 & $\begin{array}{l}\text { The ability of employees } \\
\text { to deal with pain }\end{array}$ & 48 & 81 & 19 & 2 & 0 & 3,566 & 0,898 \\
\hline 27 & $\begin{array}{l}\text { The ability of employees } \\
\text { to overcome the quality of } \\
\text { life }\end{array}$ & 50 & 81 & 19 & 0 & 0 & 2,640 & 0,887 \\
\hline 28 & $\begin{array}{l}\text { The ability of employees } \\
\text { to overcome life risks }\end{array}$ & 39 & 91 & 20 & 0 & 0 & 2,615 & 0,881 \\
\hline 29 & $\begin{array}{l}\text { The ability of employees } \\
\text { to view holistically the } \\
\text { problems in their lives }\end{array}$ & 50 & 79 & 19 & 0 & 0 & 2,598 & 0,933 \\
\hline & Average & \multicolumn{7}{|c|}{3,158} \\
\hline & Standard Deviation & \multicolumn{7}{|c|}{0,994} \\
\hline & Range & \multicolumn{3}{|c|}{2,164} & s/d & \multicolumn{3}{|c|}{4,152} \\
\hline & Category & \multicolumn{3}{|c|}{ Poor } & s/d & \multicolumn{3}{|c|}{ Good } \\
\hline
\end{tabular}


Recapitulation of the results of respondents' answers regarding the competency variable has an average of 3.158 with a standard deviation of 0.994 stated as not good to good, this indicates that employees in Sumut Bank of Sharia Unit, North Sumatera are still not good, this indicates that employees need training to support in the field sharia in order to achieve company goals. Even so employees always try to understand the tasks assigned to him with a system that has been determined by the company. Judging from the largest average of 3,800 with the smallest standard deviation of 0.858 , it shows that the indicator of employee's ability to express inhalation means that the employee actually has the ability to carry out their duties but is still not maximal. In addition, the other biggest indicator is the ability of employees in mastering information at 3,800, with a standard deviation of 0.867 .

\subsection{Competency Analysis}

Competence is an individual's ability resulting from learning and experience in carrying out his work effectively and with good behavior based on established guidelines. can be related to performance in a causal flow model, which shows that goals, temperaments, selfconcepts, and knowledge which then estimates performance includes intentions, actions and final results. For example, motivation for achievement, a strong desire to do better than the standard measures that apply and to achieve maximum results, shows the possibility of entrepreneurial behavior, setting goals, taking responsibility for the final results and taking calculated risks.

Based on the results of descriptive analysis obtained an average value of 3,158 with a standard deviation of 0.994 stated as not good to good, this indicates that employees in Sumut Bank of Sharia Unit, North Sumatera are still not good, this indicates that employees need training to support in the field of sharia in order to achieve company goals. Even so employees always try to understand the tasks assigned to him with a system that has been determined by the company.

\subsection{Effect of Competence on Increasing Work Motivation}

Based on the results of research and data processing, it can be seen that the competency variable has a direct or indirect effect on Increasing Work Motivation. The direct effect of the Competency variable is $5.52 \%$ the indirect effect through Leadership is $5.85 \%$, the indirect effect through Organizational Culture is $4.28 \%$ and the total effect is $15.65 \%$, meaning that competence contributes in shaping the Increased Work Motivation by $15.65 \%$ so that when competence increases then motivation will increase by $15.65 \%$. This shows that the competency variable has a significant effect on the Increased Employee Competence on Increasing Employee Motivation in Sumut Bank of Sharia Unit, North Sumatera.

These results are consistent with what was stated by Robert L. Mathis and John H. Jackson (2009) who said that one's work motivation is increasing due to the person acting better by increasing the ability and skills to achieve a goal. In addition, research conducted by Wibowo (2011: 381) which suggests that to build motivation can be done by: assessing attitudes, possessing abilities and expertise that encourage employee initiative to be motivated to work. McClelland's research results, (2008) states that a person is considered to have high achievement motivation, if he has a desire to perform better than others in the same situation. Thus there is an influence between the Increased Employee Competence on Increasing Employee Motivation in Sumut Bank of Sharia Unit, North Sumatera. 


\section{Conclusion}

Competence in Sumut Bank of Sharia Unit, North Sumatera is perceived as poor to good. The highest average value is an indicator of the ability of employees to express narratives, meaning that employees actually have the ability to carry out their duties but are still not optimal. Nevertheless there are still some weaknesses in the indicator of the ability of employees to holistically look at problems in their lives. The experts also agree with the findings of researchers, and said competence still dominates important factors in the banking business, even sharia bank employees need to have special competencies.

Competence has a significant effect on increasing work motivation. The magnitude of the influence of organizational culture on increasing work motivation by $15.65 \%$ which is the smallest effect on increasing work motivation rather than transformational leadership and organizational culture.

\section{References}

Amstrong, Michael dan Murlis, Helen, 2003, "Reward Management" A Handbook Remuneration Strategy And Practice. Fourt Edition.

Daft, Richard L 2002,. Manajemen(Jilid 1, Edisike-5), Erlangga, Jakarta,

Dessler, Gary, 2006, ManajemenSumberDayaManusia, Terj. Edisike- 10 jilid 1, Indeks, Jakarta.

DidiTurmudzi, 2012, BudayaOrganisasi, Prisma Press, Bandung.

Kotter P. JhondanHeskett L. James, 2007, "Coorporate Culture and Performance", Dampak Budaya Perusahaan terhadap Kinerja, Person Education Asia, Jakarta.

Mathis, Robert Ldan John H. Jacson, 2006, Human Resource Management (Manajemen Sumber Daya Manusia). Ed ke- 10, Salemba Empat, Jakarta.

Mondy R Wayne, 2008,“ Manajemen Sumber Daya Manusia” Edisi - 10 Jilid 2, Penerbit Erlangga, Jakarta.

Montana, Patrick J. \&Charnov Bruce H, 2008, Management (Fourth Edition), Barron's, New York.

Raymond A. Noe, Jhon R.H., Barry G. Patrick M.W, 2010, Manajemen Sumber Daya Manusia, Mencapai Keunggulan Bersaing. Buku 1. Edisi Keenam, Penerbit Salemba Empat, Jakarta.

Riani, Asri Laksmi, 2011,Perspektif Kompensasi. (cet. Ke-2), Yuma Pustaka, Surakarta.

Rivai, H. Veithzal dan Ella Jauvani Sagala., 2009. Manajemen Sumber Daya Manusia Untuk Perusahaan, PT. Raja Grafindo Persada, Jakarta.

Rivai, H. Veithzal, et. al, 2008, Performance Appraisal, Edisi ke- 2, PT. Raja Grafindo Persada, Jakarta.

Sedarmayanti, Hj, 2009, Manajemen Sumber Daya Manusia Reformasi Birokrasi dan Manajemen Pegawai Negeri Sipil, Aditama Bandung.

Simamora, Henry, 2004, Manajemen Sumber Daya Manusia, STIE YKPN, Yogyakarta.

Soekarso,. 2010, Teori Kepemimpinan, Mitra Wacana Media, Jakarta.

Sutrisno, Edi. 2010,Budaya Organisasi, Kencana, Jakarta.

Sunyoto, Danang dan Burhanudin, 2011,Perilaku Organisasi, Caps, Yogyakarta.

Tika, H. Moh. Pabundu, 2010, Budaya Organisasi dan Peningkatan Kinerja, Bumi Aksara, Jakarta.

Tjahjono, Herry, 2010, Culture Based Leadership, Kompas Gramedia, Jakarta.

Widayatmini dan Luqman Hakim. 2008. Hubungan Kepemimpinan, Kompensasi dan Kompetensi Terhadap Kinerja Pegawai Dinas Kesehatan Kota Depok. No. 2 Vol. 13 di: 
http//ejournal.gunadarma. ac.id/index.php/ekbis/article/view/308/247 diakses tanggal 15 Mei 2010

Wijaya, Muksin. 2005. Kepemimpinan Transformasional di Sekolah dalam Meningkatkan Outcomes Peserta Didik, Jurnal Pendidikan Penabur No. 5/Th. IV/Desember 2005

Kusdi. 2008. Membangun Organisasi melalui Pendekatan Budaya. Universitas Brawijaya Malang

Undang-undang Ketenaga kerjaan No 13 tahun 2003, pasal 1ayat 10 